\title{
Case Analysis on Accounting and Tax Treatment for Business Combination under Identical Control in China
}

\author{
Chen Huimin ${ }^{1}$ china \\ guoermi@126.com
}

Keywords: Business Combination under Identical Control; Financial Accounting; Tax Treatment; Taxable Combination; Tax-Free Combination.

\begin{abstract}
According to the provisions of the accounting standard for business enterprises, under the same control enterprise merger and not under the same control enterprise merger accounting methods are different. At the same time, processing of the tax law are also different. Understanding the difference of accounting and tax treatment for our enterprise financial management has a very important effect. In this thesis, I mainly discuss the difference between under the same control enterprise merger accounting processing method and tax treatment processing method. I will be in the form of case study showing they are different.
\end{abstract}

\section{Analysis on method of accounting for business combination}

Business combination under identical control. This mode means that under the control of the same party, one enterprise acquires equity or net asset from other enterprise or enterprises. All parties that participate in business combination are controlled by the same party or parties before and after combination, and such control is permanent. As for business combination under identical control, pooling of interest method is often adopted as accounting treatment method. In another word, assets and liabilities of the combined party will be verified according to the original book value, and the goodwill will not be confirmed according to this. The combining party will appropriately adjust capital reserve according to the difference between book value of the assets gained and combination consideration paid. In this paper, business combination under identical control is discussed.

\section{Tax treatment principle for business combination}

\section{Tax exemption conditions about business combination in tax policy}

In Notification for Issues of Handling Corporate Income Tax in Enterprise Restructuring of CaiShui 【2009】 No. 59, "taxable" and "tax-free" behaviors in business combination behavior are defined. Behaviors that meet the following conditions can apply tax-free stipulations, and there is no need to pay corporate income tax. Otherwise, it will be thought as transfer for fair value of assets and corporate income tax must be paid (not involving relevant provisions of non-resident enterprise merger).

1. There is a reasonable commercial object, and the major purpose is not to reduce, exempt or postpone tax payment;

2. Asset or equity ratio of the acquired, merged or separated divisions meets the ratio stipulated in the notification;

3. The enterprises do not change the original substantial operation activities within 12 months after 
restructuring;

4. Payment amount of equity involved in consideration of restructuring transaction meets the ratio stipulated in the notification;

5. The original principal shareholders that gain equity payment in enterprise restructuring should not transfer the equity gained within 12 months after restructuring;

6. During business combination, equity payment amount gained by shareholders of the enterprise should not be lower than $85 \%$ of the total transaction amount; as for business combination under identical control in which there is no need to pay consideration, special tax treatment stipulations can be selected;

Equity payment means that the combining party adopts equity and share of the enterprise or the holding company as payment method; non-equity payment means that the combining party adopts cash of the enterprise, bank deposit, accounts receivable, as well as negotiable securities, inventory, fixed assets, other assets and assumption of debts except equity or share of the enterprise or the holding company as payment method. This point is almost consistent with definitions in accounting standards.

Tax treatment in taxable combination . Consideration paid by the combining enterprise contains non-cash assets; this part should be treated as sales, and corporate income tax must be paid. Costs of relevant assets and liabilities of the combined enterprises received in business combination should be determined according to the appraisal value during tax assessment. The combined enterprises and shareholders need to deal with income tax as per liquidation, and losses of the combined enterprises should not be carried over and compensated in the combining enterprise.

Tax treatment in tax-free combination. Exceptincome taxes of non-equity payment and non-monetary payment which are treated as sales, the combining enterprise bears no other taxes. The combining enterprise will take over all assets of the combined enterprises including assessable cost, which should be based on original net book value of the combined enterprises. The combining enterprise should bear income taxes of the combined enterprises, and losses of the combined enterprises can be compensated by the combining enterprise within the limited amount. It is noticeable that the so-called "tax-free combination" is just temporary tax exemption for asset transfer of the combined enterprises. If the assets are transferred or the structural cost of assets is consumed in the future, tax amount payable should be calculated according to the original assessable cost.

\section{Analysis and cases of accounting treatment and tax treatment for business combination of different types under identical control}

\section{Consolidation by merger under identical control}

Taxable combination treatment for consolidation by merger under identical control. The combining parties will set the book value of identifiable assets and debts as entry value, and the tax base is the fair value of identifiable assets and debts of the combined party on the acquisition date. The difference between these two forms temporary difference; relevant deferred income tax should be determined and reckoned in income tax expense of the current period. If the combination has commercial essence and fair value of the consideration can be measured reliably, disposal or sales profit and loss of non-monetary assets should be determined, and corporate income tax must be paid.

Tax-free combination treatment for consolidation by merger under identical control. The combining parties will set book value of identifiable assets and debts as entry value, and the tax base is the book value of identifiable assets and debts of the combined party on the acquisition date. No 
temporary difference is formed. If the combination has commercial essence and fair value of the consideration can be measured reliably, disposal or sales profit and loss of non-monetary assets should be determined, and corporate income tax must be paid.

Case analysis. North Company of China Teda Group (hereafter referred to as North Company for short) and Kuntai Power Generation Co., Ltd. (hereafter referred to as Kuntai Company for short) are two power enterprises under identical control, and the ultimate control party is China Teda Group (hereafter referred to as Teda Group for short). In 2010, North Company planned to absorb Kuntai Company and the two companies adopted the same accounting policy; base date of combination was 30 Jun. 2010. Suppose that the two companies adopt the same tax treatment mode under the control of Teda Group. Book value owned by the combined party on the combination date was: bank deposit, 1,800; account receivable, 80; inventory, 1,020; fixed asset, 230,000; short-term loan, 8,500; account payable, 3,100; long-term loan, 120,000;

The first combination method: North Company issues 500 million shares to shareholders of Kuntai Company on 30 Jun. 2010 (each share has a face value of 1 Yuan and market price of 3.43 Yuan), so as to carry out consolidation by merger for Kuntai Company.

The second combination method: North Company issues 400 million shares to shareholders of Kuntai Company (each share has a face value of 1 Yuan and market price of 3.43 Yuan), and pays monetary capital of 343 million Yuan to Kuntai Companyon 30 Jun. 2010, so as to carry out consolidation by merger for Kuntai Company.

The third combination method: North Company adopts monetary capital of 215 million Yuan and fixed asset with a book value of 1 billion Yuan and fair value of 1.5 billion Yuan as considerationon 30 Jun. 2010, so as to carry out consolidation by merger for Kuntai Company.

\section{Analysis: (1) The first combination method}

Accounting treatment of the combining party on acquisition date:

Debit: Bank deposit $\quad 1,800$

Account receivable $\quad 80$

Inventory $\quad 1,020$

Fixed asset $\quad 230,000$

$\begin{array}{cc}\text { Credit: Short-term loan } & 8,500 \\ \text { Account payable } & 3,100 \\ \text { Long-term loan } & 120,000 \\ \text { Capital stock } & 50,000 \\ \text { Capital reserve } & 51,300\end{array}$

\section{(2) The second combination method}

1,Accounting treatment of the combining party on acquisition date:

Debit: Bank deposit $\quad 1,800$

Account receivable $\quad 80$

Inventory $\quad 1,020$

Fixed asset $\quad 230,000$

$\begin{array}{cl}\text { Credit: Short-term loan } & 8,500 \\ \text { Account payable } & 3,100 \\ \text { Long-term loan } & 120,000 \\ \text { Capital stock } & 40,000\end{array}$




$\begin{array}{lr}\text { Capital reserve } & 27,000 \\ \text { Bank deposit } & 34,300\end{array}$

Debit: Income tax expense $\quad \mathrm{xxx}$

Credit: Deferred income tax liability $\mathrm{xxx}$

Debit: Deferred income tax asset $\mathrm{xxx}$

Credit: Income tax expense $\quad \mathrm{xxx}$

2. North Company should not carry over and compensate the losses of Kuntai

Company .

\section{(3) The third combination method}

Accounting treatment of the combining party on acquisition date:

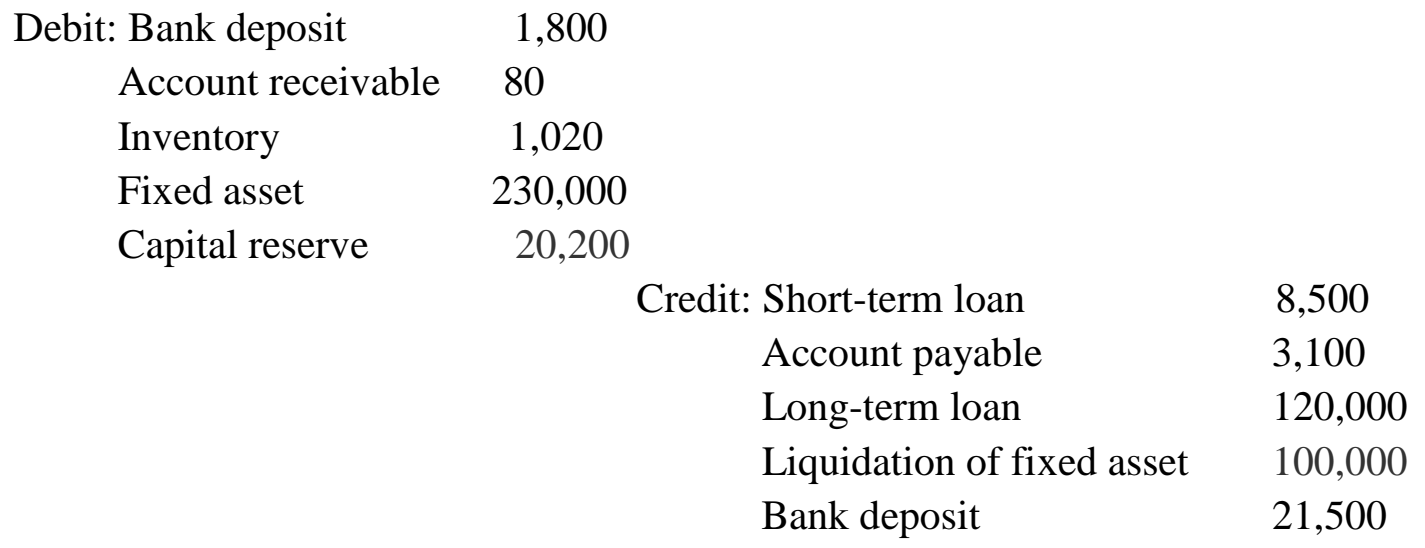

Debit: Income tax expense $\quad \mathrm{xxx}$

Credit: Deferred income tax liability $\quad x x x$

Debit: Deferred income tax asset $\quad \mathrm{xxx}$

Credit: Deferred income tax expense $\quad x x x$

Acquisition of majority interest under identical control. Notification for Issues of Handling Corporate Income Tax in Enterprise Restructuring of CaiShui 【2009】 No. 59 stipulates, "During business combination, equity payment amount gained by shareholders of the enterprise should not be lower than $85 \%$ of the total transaction amount; as for business combination under identical control in which there is no need to pay consideration, special tax treatment stipulations can be selected". Therefore, acquisition of majority interest under identical control belongs to taxable combination.

The book value of net identifiable assets gained by the combining party is used as entry value of long-term equity investment, and the tax base for long-term equity investment is the cost of the combining party on the acquisition date; the difference between these two forms temporary difference, and deferred income tax asset or liability should be determined. If the combination has commercial essence and fair value of the consideration can be measured reliably, disposal or sales profit and loss of non-monetary assets should be determined, and corporate income tax must be paid.

【Case 2】 Party A and Party B are subsidiary companies of Party C. Party A gained $60 \%$ of Party B's shares with monetary capital of 10 million Yuan on 1 Mar. 2008, and the book value of Party B's net assets on the combination date was 20 million Yuan. 
Accounting treatment of the combining party:

Debit: Long-term equity investment $\quad 12,000,000$

$$
\begin{array}{cc}
\text { Credit: Capital reserve } & 2,000,000 \\
\text { Bank deposit } & 10,000,000
\end{array}
$$

Tax treatment of the combining party: The tax base for long-term equity in corporate income tax is 100 million Yuan, and corresponding deferred income tax liability should be determined.

Debit: Income tax expense $\mathrm{XXX}$

$$
\text { Credit: Deferred income tax liability } \quad \text { xxx }
$$

\section{Conclusion and analysis}

The differences between accounting treatment and tax treatment of the combining party under identical control are summarized in the following table.

\begin{tabular}{|l|l|}
\hline \multicolumn{1}{|c|}{ Item } & $\begin{array}{l}\text { Business combination } \\
\text { under identical control }\end{array}$ \\
\hline Tax-free combination & $\begin{array}{l}\text { Book value of asset = } \\
\text { Original book value of } \\
\text { the combined party } \\
\text { Tax base for asset = } \\
\text { Original book value of } \\
\text { the combined party } \\
\text { No temporary } \\
\text { difference }\end{array}$ \\
\hline Taxable combination & $\begin{array}{l}\text { Book value of asset }= \\
\text { Original book value of } \\
\text { the combined party } \\
\text { Tax base for asset }= \\
\text { Fair value of the } \\
\text { combined party } \\
\text { With temporary } \\
\text { difference }\end{array}$ \\
\hline
\end{tabular}

\section{References}

[1] Chen Xin yuan. China's listed companies convertible merger accounting method choice: case analysis and realistic thinking [J]. Journal of accounting research, 2001, (5)

[2] Ya-hong wang based on under the same control enterprise merger accounting problems of analysis and research [journal] - ranked 2013 (5)

[3] Journal articles discuss the same control and not of the same control enterprise merger - China's agriculture accounting - 2011 (12) 
[4] 《Tax accounting》 Zhengwei

[5] Journal articles in combination with rights and purchase method in the application of enterprise merger - China township enterprise accounting - 2010 (8)

[6] Journal articles under the same control business merger accounting treatment and the use of "the principle of caution" - business - 2013 (2)

[7] 《Senior financial management》Unified national examination for certified public accountants

[8] 《Tax law》Unified national examination for certified public accountants

[9] Journal articles under the same control holding merger compared with absorption merger accounting treatment - business accounting - 2011 (4)

[10] Journal articles the long-term equity investment and enterprise merger accounting to explore China township enterprise accounting - 2010 (4) 